\title{
Toplumsal Cinsiyet Eşitsizliğinin İrrasyonelliği ve Kamusal Alandaki Yansımaları
}

\section{Irrationality of Gender Inequality and Reflections in the Public Sphere}

\author{
Aziz Șeker* \\ Amasya Üniversitesi, Amasya, Türkiye
}

\begin{abstract}
Öz
Bir toplum içinde kadının sosyal durumu, o toplumun toplumsal yapısına ilişkin genel özellikleri hakkında bilgi verir. Toplumsal cinsiyet eşitsizliği kadınlar söz konusu olduğunda toplum tarihi içinde; politika, çalışma yaşamı, sanat, aile gibi alanlarda küresel bir insan hakları sorunu ve bir sosyal sorun olarak yaşanmaktadır. Bu nedenle toplumsal yapı çözümlenirken, kamusal alanın yanı sıra mahrem alanda kadınlarla ilgili eşitsizliklerden yola çıkılmaktadır. Bu anlamda kadına yönelik şiddet üzerine bir bakış açısı geliştirmeyi düşünüyorsak, toplumsal cinsiyet kavramını kendi tarihselliği ve dinamiği içinde işlemeyi önceliklerimiz arasına alırız. Çünkü kadın aleyhine olan bir toplumsal cinsiyet hiyerarşisini kabullenmek kadına ve kız çocuğuna yönelik tutumların gerekçeleri açısından bir tartışma alanı açmaktadır. Bu çalışmada toplumsal cinsiyet eşitsizliği açısından kadınlığın durumu küreselleşme, yoksulluk, medya, kadına yönelik şiddet, edebiyat vb. olgular üzerinden gidilerek değerlendirilirken, kadını dışlayan ve aşağılayan (mizojinik) koşullara ilişkin sosyolojik bir çözümleme yapılacaktır. Ayrıca toplumsal gelişme ve kadın olgusunu görmek açısından toplumsal cinsiyet eşitsizliğini besleyen koşullar kritik edilecektir.
\end{abstract}

Anahtar Kelimeler: Toplumsal Cinsiyet Eşitsizliği, Kadına Yönelik Şiddet, Sosyal Sorun, Medya, Edebiyat.

\begin{abstract}
The social status of women in a society gives information about the characteristics of the social structure of that society. Gender inequality is experienced as a global human rights problem and a social problem in the fields of politics, working life, art and family when it comes to women. Therefore, while the social structure is being analyzed, inequalities related to women in the private space as well as the public space are taken into consideration. In this context, if we intend to develop a perspective on violence against women, we prioritize the concept of gender within its historical background and dynamics. This is because accepting a gender hierarchy against women opens a field of discussion in terms of the causes behind the attitudes towards women and girls. In this study, the status of womanhood in terms of gender inequality will be evaluated through globalization, poverty, media, violence against women, literature etc., and a sociological analysis of the conditions that exclude and degrade women (misogynist attitudes) will be provided. Furthermore, in order to see the relations between social development and status of women, the conditions that nurture gender inequality will be criticized.
\end{abstract}

Keywords: Gender Inequality, Violence Against Women, Social Problem, Media, Literature. 


\section{Giriş}

Kadının toplumsal tarihi, günümüzde bir sosyal sorun odağı olarak kabul edilen toplumsal cinsiyet eşitsizliğinin, mahrem ve kamusal alanda çeşitli olumsuz yönleriyle yaşanmaya devam ettiğini göstermektedir. $\mathrm{Bu}$ olumsuzlukların sürmesinde sosyolojik olarak ataerkil toplumsal inşanın önemli bir etken olduğunu söylemek mümkündür. Öteden beri kadının yaşamını ve kimliğini büyük ölçüde belirleyen ataerkil gelenekler, kadının doğal ortamının evin içi olduğunu ileri sürerken, bu süreci adeta kurumsallaştırmıştır. Bireylerin doğdukları topluluk içinde sosyalleşmeleri kadınlar söz konusu olduğunda, toplulukta geçerli olan değerler ve sabit buyrukların etkisinin altında kalır. Kadınlar açısından modernliğin eşiğine ve hatta ondan çok sonrasına kadar gelen dönemde bile toplumsal cinsiyet farkl111kları geleneklerde derinlemesine kutsallaştırılırken, yerleşik iktidarlar tarafından da desteklenmiştir (Giddens, 2008, s. 101; 2011, s. 81). Ayrıca insanlık tarihi boyunca eril deneyimin evrensel kabul edilmesi, sadece kadınların tarihini gizlemekle kalmadığı gibi erkek deneyiminin kendi başına analiz edilmesini de engellemiştir (Hanks Weisner, 2020, s. 2). Bunun sonucunda cinsiyet, toplumsal cinsiyet boyutuyla tahakküm kurma aracına dönüştürülmüştür. Başka bir deyişle, biyolojik açıdan cinsiyet erkek ve kadın bedenindeki farklılıklarla ifade edilirken, toplumsal cinsiyet erkekler ve kadınlar arasındaki psikolojik, sosyal ve kültürel anlamlandırmalarla ele alınmıştır. Kültürel ve sosyal yapının koşulladığı cinsiyetle özdeş tutulan farklılıklar için cinsiyet rollerini öğrenecek çok sayıda kamusal aracın bu ayrıştırıcı süreci katı kurallarla yönlendirdiği kabul edilir (Giddens ve Sutton, 2014, s. 185). Dolayısıyla toplumsal cinsiyet rolleri, kadınlara tanınan özgürleşme olanaklarına göre çeşitli kültürlerde ve toplumlarda birbirinden farklı olsa da var olmaya devam etmektedir. Cinsiyetlere toplumsal mekanizmalar tarafindan atfedilen roller bütünü, kuşkusuz, toplumların siyasetinden ekonomisine, coğrafyasından tarihine kadar çok değişik faktörler tarafından biçimlendirilirken, uzun dönemler boyunca kadınların aleyhine işleyen mizojinik göstergelerin kamusal ve mahrem alanda üretilmesine ve toplumsal bellekte yer etmesine kaynaklık etmiştir. Sonuçta toplumsal kurumlar aracılığıyla her iki farklı cinsiyet olan kadın ve erkek, toplumsal cinsiyet üzerinden dönüşürken, bir tarafta kişisel düzeyde kadınlık ve erkeklik, diğer tarafta toplumsal-ekonomik düzeylerde bir cinsiyet rejimini oluşturmuştur. Kavram olarak cinsiyeti aşan bu gerçeklik, toplumsal yapılarla ve ilişkilerle bağlantılı bir hâl alırken, toplumun her toplumsal cinsiyetten beklentisi ekonomik ilişkiler başta olmak üzere kamusal alanda toplumsal cinsiyet eşitsizliğiyle anılmaktadır. Bu noktada toplumsal cinsiyet, cinsiyetleri kurgulayan üretim mekanizmasının kendisiyle özdeşleşirken toplumsal cinsiyetin ortaya çıkışı çok boyutlu bir süreç olarak şekillenmektedir (Üstün ve Bora, 2005, s. 41; Butler, 2014, s. 52).

Cinsiyeti toplumsal yapıda, sosyal inşa temelinde sosyal-kültürel koşullanma dinamiğinden ayrı ele almamak gerekir. Toplumsal cinsiyet sosyal inşa sürecinde belirlenmektedir. Toplumsal cinsiyete ilişkin algılar, toplumsal değişme sürecinin bir parçası olarak dönüşmekte ve toplumsal cinsiyetin kazanılmasında aile başta olmak üzere bütün toplumsal kurumların etkisi olmaktadır. Sosyalleşme boyunca kadın ve erkeğe ilişkin rolleri öğrenen birey farkına varmadan, toplumun ondan beklediği haliyle davranmaya başlamakta ve sürekli toplumsal cinsiyete ilişkin kalıpları yeniden öğrenerek pekiştirmektedir. Bunların belirlediği cinsiyet hiyerarşisi ise toplumsal cinsiyeti üretmektedir. Böylece toplumsal cinsiyeti üretip pekiştiren toplumsal cinsiyet hiyerarşisi ortaya çıkmaktadır. Diğer yandan toplumsal cinsiyete dayalı baskının farklı kültürlere özgü işleyiş̧lerini tanıyamamaksa kültürel farklılıklarla ilgili tartışmaları gündeme getirmektedir (Zeybekoğlu, 2013, s. 113; Butler, 2014, ss. 17-61).

Toplumsal cinsiyet sosyolojisi çalışmalarında dikkat çeken güç ilişkilerine odaklı cinsiyet rejimi kavramı, cinsiyetin inşa edildiği iktidar koşullarında ortaya çıkmıştır. Cinsiyet rejimi kavramı, aynı zamanda, bu ilişkilerin 'kültür' ve 'gelenek' gibi gevşek terimlerle nitelenmesine karşı politik bir patriyarkanın ifadesi olarak kabul edilmektedir. Ayrıca cinsiyetin içinde kurulduğu toplumsal ilişkilerin birer iktidar ilişkisi olduğunu, bu ilişkilerin belirli ve kavranabilir bir sistematiğinin bulunduğunu, bu sistematiğin toplumdaki bütün iktidar ilişkileri ve yapılarıyla etkileşim içinde işlediğini iddia eder. Bu kavramlar ancak birlikte düşünüldügünde hem özneye hem de toplumsal yapı ve ilişkilere analitik bir çerçeveyle bakabilme olanağı sağlarlar (Üstün ve Bora, 2005, s. 13). 
Toplumsal cinsiyetin kurumsallaşması ile gelen toplumsal cinsiyet eşitsizliği öncelikle kadınlar açısından bir sosyal sorun olarak değerlendirilmektedir. Toplumsal cinsiyet ayrımcılığına maruz kalan kadınlar siyasal, yasal, sosyal ve ekonomik hakları kullanmada, toprak ve sermaye gibi kaynaklara sahiplikte eşitsizliklere uğramaktadırlar. Çalışma sürelerine göre dünya gelirine ve mülkiyete sahip olmaları konusundaki aşağı statüleri ağırlıklı sorun olmaya devam etmektedir (Üner, 2008, s. 7). Diyebiliriz ki, yaşamda erkeklerin bıraktıkları sorumlulukları da benimsemek zorunda kalan kadınlar, erkeklerin elde ettiği ekonomik bağımsızlığa erişememişlerdir. Konuyla ilgili şöyle ilginç bir örnek verilebilir; günümüzde Batı'da yoksulların önemli bir yüzdesini özellikle tek ebeveynli ailelerin başındaki kadınlar meydana getirmektedir (Giddens, 2014, s. 150). Bir bütün halinde toplumsal cinsiyete bakıştaki temel sorun birçok sosyal soruna eklemlenerek kısırdöngüye dönüşürken, iş gücü piyasası ve diğer sektörlerde de kadın aleyhindeki koşullar, kadın kimliği üzerinden sorunlar yaşanmasına neden olmaktadır. Tahmin edileceği gibi, bu ve bunun gibi rasyonel olmayan durumların olumsuz sosyal sonuçlarından daha çok toplum zarar görmektedir. Oysa insanın özgür ve eşit doğduğu hep vurgulanır. İnsanoğlu belki özgür ve eşit doğuyor ama doğumla birlikte eşitlik bitip eşitsizlik de başlıyor. Konu kadın olduğunda ise özellikle sosyal ve kültürel dünyada özgürlük ve eşitlik sorunu daha karmaşık bir hâl almaktadır (Güvenç, 1991, s. 306). Aşağıda toplumsal cinsiyet eşitsizliğinin yerel ve küresel ölçekte kadınlar açısından eşitlikçi olmayan, insan onur ve haysiyetini olumsuz etkileyen sosyal sonuçları çeşitli açılardan irdelenmiştir.

\subsection{Küreselleşme Sürecinde Kadın Göçü ve Toplumsal Cinsiyet Eşitsizliği}

Cinsiyetçilik praxis'ine göre bütün insanların hakları aynı olmayıp, biyolojik ya da kültürel açıdan kesin bir hiyerarşik sıra oluşturur. İnsanların haklarını ve ayrıcalıklarını, ayrıca kolektif çalışma süreci içindeki yerlerini bu hiyerarşi belirler. Bu, bazı grupların diğerlerine göre doğuştan farklı ve daha başarılı olmaları olgusuyla açıklanarak gerekçelendirilmektedir (Wallerstein, 2012, s. 134). Küreselleşen dünyada kadınlar, bu hiyerarşide çalışma yaşamında ucuz iş gücü olmaya devam etmektedir. Ev içi (bakım elemanı) süreçlerden tutun da tarım sektörüne kadar birçok alanda kadın emeği değerlendirilmektedir. Çoğunluk ücretsiz işgücü statüsündedirler. Diğer yandan küreselleşmenin bir sonucu olarak ekonominin yeniden yapılandırılması cinsiyet ilişkileri bakımından belli sonuçlar ortaya çıkarmıştır. Birincisi küresel çapta 'iş hayatının kadınlaşmasına' neden olmuştur. Ekonomik küreselleşme aynı zamanda 'göçün kadınlaşmasına' neden olan dinamikleri serbest bırakmıştır. Gelişmekte olan ve gelişmiş dünyadaki baskılar, bu eğilime katkıda bulunmaktadır. Küreselleşme sürecinde kadın göçünün önemli bir kısmı kayıt dışı ve gayri resmi yollardan gerçekleştiğinden, kadın işçiler ayrımcılığın, sömürünün ve tacizin en kötü biçimleriyle karşılaşır. Örneğin ulaşım ve yerleşim harçları için borçlarına karşılık onlara iş bulan kuruluşlar tarafından rehin tutuldukları, işverenleri tarafından evlere hapsedildikleri, insanlık dışı muameleye maruz kaldıkları ve hatta bazen öldürüldüklerine rastlanılmaktadır. Yine giderek artan göçmen kadınlar, cinsel tacizlerin, fuhuş sektörü için yapılan insan ticaretinin ve fahişeliğin kurbanları arasında yer almaktadır (Heywood, 2013, s. 505-506; Ritzer, 2011, s. 473).

Kadın göçünün farklı nedenleri bulunmaktadır. Ülke coğrafyası içinde gerçekleşebileceği gibi gelişmemiş bir ülkeden başka bir ülkeye ev hizmetlerinde çalışmak üzere kadınlar göç edebilmektedir. Kadınların eş olarak geleneksel rolüyle bağlantılı hizmetlerin, küresel çapta transfer edilmesi en açık haliyle seks olgusunda görülmektedir. Küreselleşme çağı, seks endüstrisini ulusal ve küresel düzeyde çok ileri düzeylere taşımıştır. Kaçakçılar tarafından alınıp satılan, köle haline getirilen kadınların ve kız çocuklarının sayıları endişe verici boyutlara ulaşmıştır. Örneğin Tayland'da yarım milyonla bir milyon arasında fahişe bulunduğu ve bunların yirmide birinin köleleştirilmiş olduğu tahmin edilmektedir. Fahişelik Tayland'da 1970'li yıllardaki ekonomik genişleme sırasında hızla yaygınlık kazandı. Bunun nedenlerinden biri, erkek işçilerin hayat standartlarının yükselmesi, diğeri ise ülkenin kuzeyindeki fakir dağlık bölgede çocukların yoğun bir halde köle olarak satılmasıyla, seks endüstrisindeki arzın artmasıydı. İnsanların giderek artan küresel göçü, cinsel sömürü amacıyla kadınların nakledilmesi konusunda insan tacirlerine daha büyük firsatlar yaratmıştır. Kadınların seks sektöründe çalıştırılması amacıyla kaçırılmasının, ev işlerinde çalıştırılmak üzere kaçırılan kadınlara oranla 
çok daha zararlı sonuçları bulunmaktadır. Bunun alçaltıcı olması bir yana, bu sürecin kurbanları, cinsel yoldan bulaşan hastalıklar, HIV/AIDS, uyuşturucu alışkanlığı gibi sağlık açısından ve hayatları için tehdit oluşturan birçok riskle karşı karşıya kalmaktadır. Küresel çağda iletişim teknolojilerinde yaşanan büyük ilerleme, küresel ölçekte seks işçiliği için kullanılan yolları artırmaktadır. İnternet küresel insan tacirliğinin ve kadınların (ve çocukların) cinsel bakımdan sömürülmesinde önemli bir alan olmuştur. 'Tüketiciler' dünyanın herhangi bir yerinde anında, seks işçisi bulabilmekte, web sitelerinde teşhir edilen seks işçileri hakkındaki haberleri izleyebilmekte, nerede fahişe bulabilecekleri ve seks işçilerinin ücretleri hakkında bilgi alışverişi yapabilmektedirler. Kuzey Amerika ve Avrupa'da, Güneydoğu Asya ve Karayipler'e ticari fuhuş için açılan web sitelerinde paket turlar, teklif edilen ücretler anlatılmakta ve Kuzey'deki erkekler için seks işçilerinden ve hizmetlerinden söz eden reklamlara yer verilmektedir. Küresel düzeyde seks ticaretinin değişik boyutları bulunmaktadır. Bunlar arasında seks ticaretinin en vahşi ve sömürü niteliğindeki şekli insan kaçakçılığıdır. Dünya çapında bu tür kaçakçılığa dâhil olan insanların sayısı 4 milyonla 200 milyon arasında değişmektedir. Kadınlar ve genç kızlar bütün mağdurların yaklaşık \%80'ini oluşturmaktadır. Birleşmiş Milletlere göre, kadınların ve genç kızların \%87'si cinsel istismar amacıyla kaçırılmaktadır. Bu sorun Asya'daki belli özellikleri etkilemektedir. Örneğin her yıl 5.000 ile 7.000 arasında Nepalli kız çocuğu ve kadın Hindistan'a kaçırılmaktadır. Küresel düzlemde kadın kaçakçılığının bir başka yönüyse e-postayla ısmarlanan gelinlerle ilgilidir. E-postayla gelin 1smarlama sektörü, internet sayesinde milyonlarca dolarlık bir küresel endüstri haline gelmiştir. E-postayla gelin ısmarlama ajansları tarafindan her yıl yaklaşık 4 bin ile 6 bin arasında kadın ABD'ye getirilmektedir. Kuzey Amerika ve Batı Avrupa gibi zengin bölgelerdeki erkeklerin, denizaşırı ülkelerden özellikle Güneydoğu Asya'dan ve eski Sovyet Bloku ülkelerinden adeta 'posta siparişi' yoluyla eş getirmeleri giderek artmaktadır (Heywood, 2013, s. 506; Ritzer, 2011, ss. 474-475). Denebilir ki, toplumsal cinsiyetlendirilmiş ve cinselleştirilmiş kültürel ve ırksal farklılık kavramları eşitsiz küreselleşen ekonominin sonucunda ortaya çıkan seks turizmi kadar internet evlilik hizmetlerini de şekillendirmektedir. Erkek müşteriler, kendi ülkelerindeki kadınlara nazaran "geleneksel" toplumsal cinsiyet rollerine uymaya istekli, cinsel partnerler veya evlilik partnerleri aradıklarını bildiriyorken, seks işçileri ve koca arayan kadınlar ise bu ilişkileri yoksulluktan kurtulmak için tek çare olarak görmektedirler. Bu modelde geleneksel toplumsal cinsiyet rollerini kabul etmeyi paketin bir parçası olarak gören kadınlar büyük bir kitleyi oluşturmaktadırlar (Hanks Weisner, 2020, s. 362).

\subsection{Yoksulluk, Kadına Yönelik Şiddet ve Toplumsal Cinsiyet Eşitsizliği}

Toplumsal koşulların eşitsizliği ile erkek lehine egemen toplumsal kurumsallaşmanın, kadın yoksulluğunu istihdamda, eğitimde ve refah paylaşımında önemli oranda belirleyen bir etken olduğunu söylemek mümkündür. $\mathrm{Bu}$ olumsuzluk, yoksulluğun dinamik bulduğu kırsal toplumsal yapılarda, gecekondu vb. yerleşimlerde yoğun yaşanmaktadır. Yoksulluğun hane içi ilişkilerde en çok kadını etkilediğini, yoksulluğun getirdiği kötü şartlarla, görünmeyen bir alanda ise en çok kadınların mücadele ettiğini yapılan çalışmalar göstermektedir (Fidan, 2016, s. 85). Yoksulluğun kadın boyutunu anlamak için hem hane içi hem de hane dışındaki yapılara bakmak gerekir. Genel cinsiyet beklentileri ve eşitsizlikler, kaynaklara erişim ve kullanım anlamında yoksulluğu tetikleyen eşitsizlikleri beslemektedir. Bununla ilişkili olarak kadın yoksulluğunun toplumsal cinsiyet analiziyle genel yoksulluktan farklılaşma boyutu, toplumlarda yoksulluğun önlenmesine veya azaltılmasına yönelik çabaları içine alarak; kadınların sosyal yaşama katılabilirliğini, bireysel yapabilirliklerini, ekonomik ve sosyal sermayelerini, aitliklerini ve sosyal dışlanmışlıklarını çözümlemeye sevk eden bir tutum doğurmuştur (Körükmez, 2008, s. 219; Alptekin, 2014, ss. 15-33).

Farklı bir örnek olması bakımından, kadın yoksulluğunu fuhuş sektöründen yola çıkarak işleyen bir araştırmayı ele alalım. Mersin genelevinde ve sokakta fuhuş pazarında var olma mücadelesi veren 44 kadınla yapılmış derinlemesine görüşmelerden elde edilen veriler şu şekildedir: Kadınların sermaye olarak fuhuş pazarına çıkma yaşına baktığımızda, \%27,5'inin 13-15, \%50'sinin 16-20, \%17,5'inin $21-25$ ve yalnızca $\% 5$ 'in 25 ya da geç bir yaşta olduğu görülmektedir. Nedenler arasında erken yaşta evlilik, yoksulluk, eğitimsizlik ve parçalanmış 
ailelerden gelme oranları \%67,5 olarak belirtilmiştir (Açıkalın, 2014, ss. 290-311). Kadının kötü koşullarda cinsel sömürüsü başlı başına bir kadın düşmanlığı alanı açmaktadır. Yine örneğin Sovyetler Birliği'nin dağılması, Balkanlar'da ve Ortadoğu'da yaşanan iç savaşlarda kadınların sistem içinde konumlarının ve rollerinin değişmesiyle sürüklendikleri işsizlik durumu, farklı ülkelerde onları iş bulma süreçlerine itmiştir. Türkiye'de de rastladığımız bavulculuk ve diğer marjinal işlere yönelmeyle birlikte göçmen kadın fuhuşu artmış, bu işlerde çalışan kadınların yaşamları şiddet başta olmak üzere birçok sosyal sorunla içli dışlı bir hale gelmiştir.

Yoksulluğun etki ettiği kadına yönelik ayrımcılık toplumsal yaşamın her alanında rastlanan bir olgudur. Bu anlamda kadına yönelik şiddet birçok boyutu olan, karmaşık ve çoklu nedensellik gösteren bir özelliğe sahiptir (Erjem, 2018, s. 305). Daha çok yoksulluğun sonucunda şiddet artışı ortaya çıkmaktadır. Toplumsal dengelerin bozulduğu, gelir dağılımındaki uçurumun genişlediği, işsizlik korkusunun, yarın kaygısının yaygınlaştığı ortamlarda şiddet, her zaman, yarattı̆̆ 'öteki'ni ezerek kendini var eden bir toplumsal-psikolojik boşalım aracı olmaktadır. Öteki ise genellikle güçsüz olandır; kadınların şu anki konumu da böyledir (Demir, 2003, ss. 277285). Kadına yönelik her türlü şiddet çoğu zaman bir döngü halinde süreklilik göstermektedir. Son yirmi y1lı kapsayan birçok istatistiki çalışmada ulusal ve uluslararası düzeyde bu olgunun yaygınlığı kanıtlanmıştır. Örneğin Bangladeș'te tüm cinayetlerin yarısını eșleri tarafindan öldürülen kadınlar oluşturmaktadır (Korkut ve Owen, 2008, ss. 8-9). Türkiye açısından ise 2015 yılında gerçekleştirilen Kadına Yönelik Aile Iç̧i Şiddet Araştırması'nda önemli veriler elde edilmiştir. Örneklem olarak 15.072 hanehalkının belirlendiği araştırmanın sonuçları fiziksel ve cinsel şiddetin bir arada yaşanmasının yaygın olduğunu ortaya çıkarmıştır. Türkiye genelindeki kadınların yüzde 36'sı fiziksel şiddete, yüzde 12'si cinsel şiddete maruz kaldığını belirtirken, kadınların yüzde 38'inin iki şiddet biçiminden en az birine maruz kalması, çoğunlukla cinsel şiddetin fiziksel şiddet ile bir arada olduğunu göstermektedir. Her 10 evlenmiş kadından neredeyse 4'ünün eşi veya birlikte olduğu erkeklerin fiziksel şiddetine uğraması bir başka önemli bulgudur (Kaptanoğlu ve Çavlin, 2015, s. 80122). Burada kadına yönelik ölümle sonuçlanan şiddet olaylarına da bir parantez açmak gerekir. Kadın Cinayetlerini Durduracağız Platformunun 2019 yılı raporunda aynı yıl içerisinde erkekler tarafindan 474 kadının öldürüldügü belirtilmiştir (http://kadincinayetlerinidurduracagiz.net).

Kadına yönelik şiddetin kadınlar tarafından nasıl algılandığına dair çalışmalara da bakmakta fayda var. Çanakkale'de bir toplum merkezinde, kadına yönelik; fiziksel, ekonomik, sözel, psikolojik ve cinsel şiddet ile ilgili yapılan araştırmaya katılan 400 kadının yarıdan fazlası, hayatlarında en az bir kere fiziksel şiddete maruz kaldıklarını ifade etmişlerdir. Araştırmada kadınların, toplumsal ve ahlaki değerlerin dışına çıkarak, şiddetin yaşanmasına zemin hazırladığını düşünen kadınların oranının \%48,4 gibi bir düzeyde çıkması ilginçtir. Araştırmanın bulgularına göre, katılımcıların çoğunluğunun şiddet mağduru konumda olmalarına rağmen geleneksel kadınlık rollerinin toplumsal hayat içerisinde yeniden üretilmesi noktasında genellikle olumlu düşüncelere sahip olmaları dikkat çekicidir. Bunu destekleyici olarak, kız ve erkek çocuklarına, çocukluktan itibaren toplumsal cinsiyet rollerine uygun görev sorumlulukların verilmesinin gerekli olduğunu düşünenlerin oranı ise \%70 kadardır. Katılımcıların \%84'ü şiddeti bir insan hakları ihlali olarak görmekteyken, hukuki haklarının neler olduğunu bilenlerin oranı \%51'dir (Uluocak, Gökulu, Bilir, Karacı ve Özbay, 2014, ss. 203216).

Genel hatlarıyla bakıldığında kadına yönelik şiddetin bazı faktörlere bağlı olarak temel bulduğu görülmektedir. Kadına yönelik aile içi şiddetin ortaya çıkmasını etkileyen faktörler bireysel faktörler, ilişki faktörleri, yakın çevreye ilişkin faktörler ve toplumsal faktörler olmak üzere dört temel grupta açılanmaktadır. Şiddet riskini artıran faktörler arasındaysa iç göç, yoksulluk ve doğal felaketler sıralanmaktadır (Cornell, 2016, s. 36; Korkut ve Owen, 2008, ss. 20-23). Sonuçları açısından şiddet, kadından çocuğa kadar bütün aile bireylerini olumsuz etkilerken, sağlık bakım sisteminde olsun sosyal koruma hizmetlerinde olsun yüklü bir maliyet ortaya çıkarmaktadır. Kuşkusuz dünyanın hemen hemen her yerinde şiddeti önleyici hizmetler sunulmakta, toplumsal farkındalık ve çeşitli aşamalarda müdahale hizmetleri (adli, sağlık, sosyal hizmetler) yürütülmektedir. Diğer 
yandan yapılacak çalışmalarla kadının sosyal-ekonomik statüsünün yükseltilmesi en önemli hedefler arasında ağırlığını korumaya devam etmektedir.

\subsection{Medya ve Çalıșma Yaşamında Mizojinik Yansımalar}

Bugün sosyal yaşamı cinsiyetten bağımsız bir bakış açısından veya açıkça kadın açısından görmeye çalışan gittikçe artan bir literatür söz konusu olsa da demokratik olmayan bir medya ve iletişim sektörü, her şartta kadının aleyhine süren toplumsal cinsiyet rollerini yeniden üreten bir yapıda ve güçtedir (Eriksen, 2019, s. 199). Bu nitelikte bir sektör özellikle aile kurumu içinde sınırlandırılan kız çocuğu ve kadının rollerini yeniden üretmesi yönünden tartışmanın temel kaynaklarından biridir. Daha pratik sonuçlardan hareket ettiğimizde, kitle iletişim araçlarında toplumsal cinsiyet üzerinde kadına yönelik şiddeti olumlu ya da olumsuz haliyle yansıtan olaylara rastlamak mümkündür. Örneğin çoğu televizyon dizilerinde/filmlerinde kadının geleneksel rolleri işlenmekte, bunun dışındaki kadınlar farklı kadın olarak değerlendirilmektedir. Çoğunlukla kadının imajı ana akım cinsiyetçi kültürel inşa bakışını temsil etmektedir. Filimler ve dizilerin yanı sıra sektörün mutfağında çalışanlar arasında da kadın ikincil konumda tutulmaktadır. Beyaz perdede, gazete ve dergilerde kısaca yazılı ve görsel basında kadınlarla ilgili haberlerde bu olumsuzluklar gözlenmektedir. Yerine göre mizojinik yansımalar sessiz sedasız toplumun önüne sürülmekte; kadının yerine getirmesi gereken rollere uygun olmayan tutumu en azından söylem düzeyinde cezalandırılmaktadır. Çoğu zaman medyada toplumsal cinsiyeti üreten ve yeniden üreten süreçler süreklilik arz etmektedir. Toplumsal cinsiyet çevreden gelen mesaj ve anlam yapılarına ilişkin olarak sürekli oluşturulmaktadır. Bu sebeple medya gündelik hayatın her alanında karşılaşılan cinsiyete dayalı ayırımcılığın en görünür olduğu alanlardan birini oluşturmaktadır (Erdoğan, 2010, s. 14).

Cinsiyete dayalı ayrımcılık yalnızca medyayla sınırlı kalmamaktadır. Çocuk bakımının kadının özel alanıyla özdeş tutulması başka bir ayrımcılık türüne örnek verilebilir. Toplumsal cinsiyet rolleri ve cinsiyete dayalı iş bölümü bağlamında kadınlara yüklenen bakım işleri, toplumsal cinsiyet eşitsizliğinin temelinde yatmakta ve kadınların özel alandan çıkıp kamusal alana katılımının önünde önemli bir engel olarak varlığını korumaktadır. Kadınlar cinsiyete dayalı sorumlulukları nedeniyle ya işgücüne girememekte ya da iş taahhütlerini ve çalışma saatlerini çocuğunun ihtiyaçlarını karşılamak için azaltmak zorunda kalmakta, bu durum ise kadınların az kârlı ve az sorumluluk gerektiren işlerde yoğunlaşmalarına yol açarak işgücü piyasasındaki cinsiyetçi yapıyı pekiştirmektedir. Dolayısıyla cinsiyete dayalı iş bölümüne, aile içi bir sorun ya da sadece kadınların sorunu olarak değil, tüm toplumun yapısal bir sorunu olarak bakmak gerekmektedir. Çünkü cinsiyetçi bir pratik olan bakımın toplumsal boyutunun olduğu ve toplumun refahının önemli bir unsuru olduğu unutulmamalıdır (Bütün, 2010, s. 25). Bunları tartışırken tarihsel birikimi unutmayarak, bazı çelişkileri aydınlatması bakımından Hobsbawm'ın şu düşüncelerine eğilmekte yarar var. Hobsbawm'a göre, kadının özgürleşiminin yirminci yüzyılın en büyük tarihsel olaylarından biri olduğuna hiç şüphe yok. Onun değerlendirmesiyle yirminci yüzyılda kadının özgürleşimi, gerçekte dünyanın belli bir kısmıyla ve de toplumun belli bir kesimiyle sınırlıdı. Dünyada hâlâ bu fenomenin vuku bulmadığı pek çok yer bulunmaktadır. Bu hareket içerisinde iki büyük evre yaşanmıştır: Birincisi, aynı siyasal haklar ile seçme/seçilme hakkı için verilen mücadele; ikincisi ise, meslek ediniminde eşitlik mücadelesidir. Teknik olarak bu amaçlara İkinci Dünya Savaşı'nın bitiminden sonra ulaşılmıştır. İkinci Dünya Savaşı ertesinde kadınların oy kullanamadığı ülkeler küçük bir azınlık oluştururken, zaman içerisinde bu durum ortadan kalkmıştır. Kadınların iş hayatında ilerleme kaydetmesini olağanüstü derecede teşvik eden etmen savaş olmuştur; son otuz yılda ise bu etmen, ailelerin giderek tek gelir yerine iki gelire duydukları gereksinimdir. Kadınların üst düzey mesleki pozisyonlar ile anneliği bir arada götürmede yaşadıkları olağanüstü güçlükleri de görmek gerekmektedir. Sorunu, çocukları bakıcılara ya da anaokullarına emanet ederek, onları öz annelerinin yerine başka insanların yetiştirmesine imkân vererek çözmek kuramsal olarak mümkündür. Tarih bize bunun mümkün olduğunu söylemektedir: Aristokrasi bu uygulamaya çokça başvurmuştur. Fakat günümüzde bunun çocuklar açısından en iyi çözüm olmadığına herkes 
hemfikir. Bu, gelecek kuşaklara duygusal ve toplumsal bir bedel ödetmesi muhtemel olan bir sorundur (Hobsbawm, 2007, s. 154).

\subsection{Edebiyat ve Toplumsal Cinsiyet Eşitsizliği}

İnsan dünyasının bir parçasını, insan etkinliğinin özgün bir alanını düzenli kılma yönünde atılan her yeni adım, eski sorunları ortadan kaldırsa bile yeni sorunlar oluşturur. Her yeni adım yeni türden müphemlikler doğurur ve böylelikle-benzer sonuçlar doğuracak daha başka adımların atılmasını zorunlu kılar (Bauman, 2015, s. 213). Bu kısır bir döngü olarak değerlendirilmemelidir. Düşünümseldir, kendi içinde dönüşürken, dönüştürür de. $\mathrm{Bu}$ açıdan sorunların değişimi ve dönüşümü edebiyatın da konusu olmaktadır.

Edebiyat eleştirisinin tarihsel ve toplumsal koşulları göz ardı edemeyeceği, yazın metninin tarihi ve ideolojik konumuyla ilişkisinin kavranmasının o metnin okunması, incelenmesi, değerlendirilmesi, yorumlanması için kaçınılmaz olduğu; biçimle içeriğin ayırt edilemezliği, feminist eleştiri geleneği ve bu geleneğin getirdiği analitik ölçütler sayesinde tartışılmaz bir biçimde kanıtlanmıştır. Feminist eleştiri, kendisine dek hiçbir edebi yaklaşımın metodolojisine dâhil etmeyi akıl etmediği bir analitik araç kullandı: Kültürel olarak belirlenen cinsiyet. Değişik feminist yaklaşımlar, kâh kültürel olarak belirlenmiş kadın, kâh kültürel olarak belirlenmiş erkek rolleri ve bu rollerin yazın metnindeki izleri üzerinde durdular; sanat yapıtı açısından bu belirlenimlerin anlamını kâh uzlaşmacı kâh uzlaşmaz bir tavırla eleştirel yaklaşımlarının temeline yerleştirdiler. Kadının toplumca belirlenen konumunu her yönüyle irdeleyen feminist çalışmaların edebiyat eleştirisine asıl katkıları ise eleştirmenleri 'kadın imajı' konusunda düşünmeye zorlamak oldu. Bu niteliğiyle kadın hareketi edebiyatta kadın imgesinin, eğretileme olarak kadının, kadın motif ve temalarının, kadın yaratıcılığının incelenmesine çok büyük bir ivme kazandırdı (Parla, 2014, ss. 19-23).

Şüphesiz ki, toplumsal yaşamın farklı yüzlerinde ortaya çıkan toplumsal cinsiyetin, çeşitli sektörler içindeki konumu edebiyatın ilgisini çekmeye başlamıştır. Edebiyatın bir dalı olan roman diğer türlere göre toplumsal bütünü genişçe ele alma olanağına sahiptir. Roman kadın ve erkeğin (yazıldığı kadar LGBTİ'lerin de) yer aldığ erkeğin daha işlevsel olduğunu görmekteyiz (Şeker, 2020, s. 340). Ancak bu çelişki, edebiyatın roman türünde, toplumsal yapıyı ya da çeşitli sosyal konuları işleyiş yönleriyle kadın olgusuna roman kahramanlarından gidilerek genişçe yer verilmesini beraberinde getirmiştir. Romanlarda kadın kimliğinin türlü halleriyle karşılaşırız. Toplum içindeki kadının sosyo-ekonomik statüsü romanlarda gözlenebilmekte ve hatta roman konuları içinde yeniden üretilebilmektedir. Kadın erkek ilişkisinde ve kadın-toplum etkileşiminde toplumsal cinsiyetin roman metninde nasıl kurgulandığına rahatlıkla tanıklık edebiliriz. Bu, romana yansıyan toplumu tanımaya katkı sağlamaktadır. Toplumsal cinsiyet eşitsizliğine dair veriler sunan romanlarda, roman kahramanlarının sosyal gerçeklikleriyle gelen en yakın sorun ise yoksulluktur. Romanlarda kadın hem cinsiyetinden dolayı hem de yoksulluğu ortaya çıkaran toplumsal koşulların olumsuz etkilerini yaşayan ve yansıtan bir rolde karşımıza çıkabilmektedir.

Türk romanlarında, nesnel feminist eleştiri geleneği ortaya çıkmazdan önce kadın temsili ataerkil toplumsal yapı içinde işlenmiştir. Kadın temsilleri toplumun belirlediği sınırlarda kalmıştır. Örneğin Orhan Kemal'in romanlarında büyük şehirlere göç ve bu süreçte şehirlere tutunmaya çalışan ailelerde kadın kimliği aşağı statüdedir. Bunun yanında toplumsal cinsiyet sarmalındaki yapılarda erkek yazar tarafindan oluşturulan bir kadın imgesi vardır. Kamusal alana kadının inmesi çok ciddi ve önemli aşamalardan sonra gerçekleşmiştir. Orhan Kemal'in Gurbet Kuşları romanı İstanbul'da 1950 sonrası gecekondulaşma-yoksulluk manzaralarını konu edinmektedir. O dönemdeki toplumsal dinamikte şu sosyolojik sorunsal yer alır: Kent yoksulluğu olgusunun Türkiye'de ilk yansımaları, bilindiği üzere 1950 sonrasında ivmelendirilen kapitalist gelişmenin, kırlardan büyük kentlere göçü teşvik etmesiyle oluşan 'gecekondular'idi. Buralarda yoksulluk, sefalet manzaraları, dramlar kol geziyor olmasına rağmen, zamanında gecekondular üzerine yapılmış araştırmalarda hemen görüleceği üzere ne şimdi gördüğümüz karamsar hava ne bu denli içe dönük bir öfke ne aşağılanma ve 
dışlanma duygusu, ne de iş ve varoluşlarına karşı utanç, tiksinme hali egemendir. Bunlar neo-liberalizme karşı1ık gelen, bu ögelerin belirleyici arka planında gerçekleşen 1980 sonrası ikinci göç dalgası ile oluşan 'yeni' yoksulluğun sonuç ve ifadeleridir (Laçiner, 2011, ss. 320-321). Orhan Kemal'in roman kahramanlarında büyük şehirlere göç sürecinde yoksulluk içinde şehirlere tutunmaya çalışan insanlarda, o dönem umut ve yaşamın güzelleşeceği inancı hep vardır. Bunun karşısında ise ağırlıkla ataerkil toplumun dili, kadınları çeşitli biçimlerde nesneleştirerek ve işaretleştirerek erkek öznenin kuruluşunun araçları yapmış, dilin öznesi olma sürecini kadınlar için özellikle sorunlu kılmıştır. 'Konuşan' kadın; kamusal alanda konuşan kadın, hep öznelik ile nesnelik arasında, sözün sahibi olmak ile söz tarafından sahiplenilmek arasında kalmış, kendi içinde kendine karşı bölünmesi gerekmiştir. Sözü edilen gerçeklikleri yansıtmasıyla edebiyat, toplumsal cinsiyet açısından da hayati bir önem taşır, çünkü bir yandan toplumsal cinsiyetin hangi bağlamlarda, hangi varsayımlar yoluyla dile geldiğini açığa çıkarırken, bir yandan da aynı bağlam ve varsayımların sınırlarını gösterir, farklı söz söyleme biçimleri ve konumları yaratır (Parla ve Irzık, 2014, ss. 7-13).

Edebiyat, toplumsal cinsiyet eşitsizliği ile ilgili çalışmalara toplumsal yapıyı anlama, yorumlama ve çözümleme noktasında önemli ipuçları verebilir. Sosyolojik bir okumayla feminist edebiyat eleştirisi temeline dayanan bir edebiyat üretme pratiği, kadın için ötekileştirici olmayacaktır. Mizojini konusundaki duyarlılı̆̆ın edebi metinlerde kadının kurucu özne olarak inşa edilmesiyle birlikteliği, toplumsal cinsiyet eşitsizliği konusunda elbette gelişme adına bir işlev yüklenmiş olacaktır.

\subsection{Kadınların Güçlenmesi İçin Neler Yapılabilir?}

Cinsiyet ilişkilerinin bir süreç ve oluşum halinde kavranması gereği, bu ilişkileri çevreleyen düzenin belirgin yapısal süreklilik kazanmış boyutlarını gözlerden saklamamalıdır. Bu yapısal(laşmış) boyutlardan en önemlisi, kuşkusuz, kadınların ve kadınlığa dair anlamların evrensel anlamda süreğenlik ve yaygınlık kazanmış ikincilliği, bağlılığı ve dezavantajlı konumudur. Sosyolojik olarak tanımlanmış cinsiyet grupları içinde hiyerarşilerin mevcut olduğu gerçeği, cinsiyet ilişkileri, bütün toplumsal ilişkiler gibi, aynı zamanda bir değişim, direnç ve mücadele alanı açar (Çakır ve Alkan, 2014, ss. 229-271). Bu anlamdaki sosyal değişim ve mücadeleye Castells'in kendisine sorulan bir soruya verdiği şu yanıt örnek gösterilebilir:

Ataerkil değil de eşitlikçi olan aile yeni bir icat. Henüz orada değiliz, ama bu da bir sorunsal. İspanya'da kadınlar, erkeklerin beş katı ev işi yapıyor, çocukların faaliyetlerinin yüzde 80'i onların sorumluluğunda. Ama ataerkil aile de krizde. Genç kadınlar 'bak öyle değil, böyle yapacağız, yoksa çocuk yok,' diyor. Genellikle 'tamam, çocuk yok,' cevabını alıyorlar. Özellikle de ABD'de çocuğu olmayan ya da tek kişilik hanelerin sayısında artış gözleniyor. Bugün insanların zihinlerini ve tavırlarını değiştiren başka aile tiplerini deneyimliyoruz. Bu ailelerdeki çocuklar daha mutlu olabilirler, ama bu gelişmelere ilişkin sıkı verilere ihtiyacımız var, çünkü meseleler çok ideolojik. Şimdi ataerkil olmayan ailelerde yetişmiş çocukların ilk kuşağı büyüyor ve bu ataerkil olmayan aileye ilişkin ilk deneyimimiz olduğu için sonuçlarını görmemiz, bu şekilde çocuk yaparak nereye gittiğimizi görmemiz lazım. Ama ailede ve toplumsal ilişkilerin cinsiyet boyutundan arınmasının, ailenin ve toplumsal ilişkilerin insanlar için anlam kaynağı olarak işleme biçimini değiştireceğini sanıyorum (Castells ve İnce, 2006, s. 89).

Kadınların güçlenmelerinin cinsiyet rejiminde demokratik açılımlara yol açabilmesi, bu sınırları sorun eden, güçlenmeyle birlikte özgürleşmeyi perspektifine yerleştiren yeni anlam çerçevelerinin kurulabilmesine bağlıdır. Farklılığın ve eşitsizliğin yaşandığı özel alanda geliştirilen çeşitli güçlenme stratejilerinin kamusal bir dile tercümesi ve gerçek bir dönüşüm olanağı haline getirilmesinin yanında, kamusal alanın gerçekten bir eşitlik imkânı olabilmesi için özel alandaki engel ve sınırların ortadan kaldırılması gerekmektedir. Yoksa kamusal alan-özel alan ayıımı, kadın ve erkeklerin yaşamlarının, birbiriyle ilişkilerinin daha demokratik ve özgür olması için gayet hayati görünen bir sorun alanı olarak kalacaktır (Üstün ve Bora, 2005, s. 106). Bu yolda örneğin toplumsal cinsiyete dayalı sosyal iş bölümünü eşitlikçi bir iş bölümüne dönüştürmek için, yasal, kurumsal ve sosyal uzlaştırma mekanizmalarının oluşturulması ve işlerliğinin sağlanması büyük önem 
taşımaktadır. İş ve aile yaşamı uzlaştırma politikaları, hane ve hane halkı bakımına ilişkin ev içi iş yükü ile işyerindeki sorumlulukları bağdaştırmaya yönelik yasal, kurumsal ve sosyal destek mekanizmalarını geliştirmeyi hedefleyen politikalardır. Diğer pek çok gelişmekte olan ülkelerde olduğu gibi Türkiye de uzlaştırma mekanizmaları boyutlarıyla tam bir gelişim sağlayamamıştır. Çünkü Türkiye'deki egemen bakım rejimi, ağırlıklı olarak kadınların aile/ev içindeki işlerden tek başlarına sorumlu olduğu (haliyle ezici çoğunluğun tam zamanlı ev kadınlığını temel meslek olarak benimsediği), tek (erkek) kazananlı hane modeli çerçevesinde şekillenmiştir (İlkkaracan, 2010, ss. 8-9-17). Hiç kuşkusuz uzlaştırma mekanizmalarının varlı̆̆ 1 ve uygulanabilirliği üzerinden somut çalışmalar yapılarak, toplumsal cinsiyet eşitsizliklerinin giderilmesi kadınların sosyal statüsünü yükseltecektir. Elbette, toplumsal cinsiyet sosyolojisiyle bakıldığında toplumsal eşitsizliklerin sosyal adalet temelli giderilmesi yönünde refah istatistikleri kolay kolay kısa vadede değişmezler. Eşitsizliklerle rasyonel mücadelenin sonuçlarını görebilmek bazen uzun süreleri alabilmektedir (Zencirkıran, 2013, ss. 412-447).

Günümüzde küreselleşmenin olumsuz sonuçlarını yaşayanlar arasında dezavantajlı konumdaki kadınlar ve çocuklar en geniş sosyolojik kategoriyi oluşturmaktadırlar. Toplumsal cinsiyet eşitsizliği üzerine kurulu bir dünyanın, sosyal sorunları çözemeyeceği aşikârdır. Bu bağlamda Türkiye’ye örneğine bakalım: 2014 İnsani Gelişim Raporu'nun Toplumsal Cinsiyet Eşitsizliği Endeksi'nde (TCEE); üreme sağlı̆̆ı, kadının güçlendirilmesi ve ekonomik etkinlikler alanında 155 ülke arasında Türkiye 71'inci sırada yer almaktadır. Her 100 bin canlı doğumdan 20 kadın hayatını kaybederken ergenlik çağındaki doğurganlık oranı 15-19 yaşları arasında, her 1000 kadında 30,9'dur. Kadınların iş gücü piyasasına katılımı \%29,4'tür. Erkeklerde bu oran \%70,8'dir. Eğitim, sağlık ve ekonomik kaynakları kullanma açısından hesaplanan Cinsiyete Dayalı Gelişme Endeksinde ise kadınlarınki erkeklerden daha aşağıda göstermektedir (https://www.tr.undp.org/content/turkey/tr/home/library/human_development/hdr-2014.html). Ayrica kent ve kadın açısından değerlendirdiğimizde de cinsiyete dayalı tartışmalar karşılaşacağımız konular arasındadır: Kentlerin yapılarında ve mekânsal düzenlerinde neden toplumsal cinsiyete dayalı oldukları konusunda ileri sürülen en sağlam iddia, üretim, tüketim ve toplumsal yeniden üretimin farklı işlevlerinin ayrışmasına dayanır. Çünkü kentler, toplumsal cinsiyete dayalı norm ve kimliklerin üretim, tüketim ve yeniden üretim sürecinde önemli işlev görürler. Aynı zamanda kentlerin kendisini biçimlendiren şey evde, kamuda ve hareket halinde gündelik rutinlerin toplumsal cinsiyete dayalı oluşumu ve toplumsal gerçekliğidir (Cloke, Kantor ve Jarvis, 2012, ss. 1-135).

Son tahlilde tüm dünyada olduğu gibi Türkiye'deki kadın-erkek eşitsizliğinin temelindeki sorunların çözümü için toplumsal cinsiyet duyarlılı̆̆ının tüm plan ve programlara yansıtılması gerekmektedir. Türkiye gibi Avrupa Birliği'ne katılmak isteyen ülkeler için topluluk kazanımlarının benimsenmesi bir zorunluluk olup kadın hakları ve toplumsal cinsiyet eşitliği de bunun bir parçasını oluşturmaktadır. Bu sebeple aday ülke konumunda olan ve 3 Ekim 2005 tarihi itibariyle üyelik yönünde görüşme süreci başlayan Türkiye'den, Birliğin kadın-erkek eşitliğine ilişkin düzenlemelerinin benimsenmesi, iç hukuka ve toplumsal pratiğe aktarılması beklenmektedir. Ayrıca Birleşmiş Milletler gözetiminde gerçekleştirilen kadın konferansları sonucunda alınan kararlarda, eşitsizliklerin giderilmesi amacıyla bir strateji dâhilinde toplumsal cinsiyet bakış açısının tüm ana plan ve programlara yansıtılması gereği vurgulanmaktadır. Bu çerçevede bireylerin yaşantısını doğrudan etkileyen makro ekonomik kararların ve bu kararların yansımasını bulduğu bütçelerin de toplumsal cinsiyet duyarlılığıyla hazırlanmasına dikkat edilmelidir (Aksoy, 2006, s. 118). Her şeyden önce kadın yoksulluğunun ortadan kaldırılması yolunda sosyal politikalar geliştirmek isteniyorsa, temel çözümlerden biri kadına kendi yaşamını yönetebilme ve kontrol edebilme yeteneğini geliştirebileceği koşulları hazırlamaktır. Bu, kadına güçlü ve bağımsız olması gerektiği söylenerek değil, bilişsel, psikolojik, ekonomik ve politik güçlendirme politikalarıyla sağlanabilecek bir süreçtir. Bilmeliyiz ki, demokrasi erkek egemen bir bireysel kalkınma vaadi üzerine kurulamaz. Onun en büyük ve eşsiz özelliği herkesin özgürlüğüne hizmet etmektir (Açıkalın, 2014, ss. 290-311; Bauman, 2014, s. 49). 


\section{Sonuç}

Bu çalışmada toplumsal cinsiyet eşitsizliğinden hareketle kadını ötekileştiren durumlar; göç, yoksulluk, şiddet, medya, çalışma yaşamı ve edebiyat gibi olgular etrafında kamusal alandaki yansımalarıyla değerlendirilmiştir. Yapılan sosyolojik çözümlemenin sonuçlarına göre, hızla değişen günümüz dünyasında kamusal alanın birçok boyutunda kadınlar lehine birtakım iyileşmeler kaydedilmesine rağmen baskın ataerkil yaklaşımın varlığını koruduğunu ve toplumda kadının ikincil konumda tutulduğunu ifade etmek mümkündür. Kadın özgür ve eşit doğabilir, diğer yandan sonrasında onun onur ve haysiyetinin kabul edilmediği ya da kolayca içselleştirilmediği ataerkil sosyal sistemlerde kadını içermeyen sosyal adaletin ve sosyal refahın gerçekleşmesine dair beklentiler sonuçsuz bir tartışmadan öteye geçmez. Bütün bunlara ilave olarak gerçek bir demokrasiden ise kadının cinsiyet ayrımcılığına uğramadığı, katılımının önündeki irrasyonel engellerin kaldırıldığı, adalet temelinde yükselen bir özgürlük anlayışıyla kadının bireyselliğine verilen değerin toplumda karş1lık bulduğunda ancak söz edilebilir.

Yukarıdaki saptamalar gösteriyor ki kadının her alanda güçlendirilmesi, üzerinde çalışılması gereken yaşamsal bir konudur. Öncelikle devlet bu anlamda birincil derecede sorumluluğa sahiptir. Devletin toplumsal gerçeğe etki edecek yönde uygulayacağı sosyal politikalar çocuk, kadın ve aile eksenli toplumun demokratikleşmesinin önünü açacaktır. Bu meyanda adil olmayan toplumsal koşulların kadın ve erkek açısından eşit kılınmasının, toplumsal cinsiyetten kaynaklı önyargısal eşitsizliklerle mücadelede önemli bir insan hakları etkinlik alanı oluşturacağını belirtmek gerekir.

\section{Kaynakça}

Açıkalın, N. (2014). Yoksulluğun öteki yüzü: Fuhuş pazarında kadın olmak. A. Topçuoğlu, G. Aksan, D. Alptekin (Yay. Haz.), Yoksulluk ve kadın (ss. 290-311). İstanbul: Ayrıntı Yayınları.

Aksoy, N. (2006). Toplumsal cinsiyete duyarlı bütçeleme ve kadının statüsü genel müdürlüğünün rolü. Ankara: Kadının Statüsü Genel Müdürlüğü Yayınları.

Alptekin, D. (2014). Toplumsal cinsiyet eşitsizliği örüntüsünde kadının yoksulluğu ve yoksunlukları. A. Topçuoğlu, G. Aksan, D. Alptekin (Yay. Haz.), Yoksulluk ve kadın (ss.15-33). İstanbul: Ayrıntı Yayınları.

Bauman, Z. (2014). Bu bir günlük değildir. (D. Kizen, çev.). İstanbul: Jaguar Yayınları.

Bauman, Z. (2015). Sosyolojik düşünmek. (A. Yılmaz, çev.). İstanbul: Ayrıntı Yayınları.

Butler, J. (2014). Cinsiyet belası/Feminizm ve kimliğin altüst edilmesi. (B. Ertür, çev.). İstanbul: Metis Yayınları.

Bütün, M. (2010). Toplumsal cinsiyet eşitliği perspektifinden çocuk bakım hizmetleri: Farklı ülke uygulamaları. Ankara: Kadının Statüsü Genel Müdürlüğü Yayınları.

Castells, M., ve İnce. M. (2006). Manuel Castells’le söyleşiler. (E. Kılıç, çev.). İstanbul: Bilgi Ü. Yayınları.

Cloke, J. Kantor, P. \& Jarvis, H. (2012). Kent ve toplumsal cinsiyet. (Y. Temurtürkan, çev.). Ankara: Dipnot Yayınları.

Cornell, William R. (2016). Toplumsal cinsiyet ve iktidar. (C. Soydemir, çev.). İstanbul: Ayrıntı Yayınları.

Çakır, S., ve Alkan, A. (2014). Osmanlı İmparatorluğu'ndan modern Türkiye’ye cinsiyet rejimi: Süreklilik ve kırılmalar. F. Alpkaya, B. Duru (Drl.), 1920'den Günümüze Türkiye'de toplumsal yapı ve değişim (ss. 229-271). Ankara: Phoenix Yayınları.

Demir, S. (2003). Kadın ve yoksulluk. G. Erdost, (Yay.Haz.), Türkiye insan hakları hareketi konferansı 2002 (ss. 277-285) Ankara: Türkiye İnsan Hakları Yayınları.

Erdoğan, M. T. (2010). Toplumsal cinsiyet eşitliğinin sağlanmasında medya okuryazarlı̆̆ının rolü. Ankara: Kadının Statüsü Genel Müdürlüğü Yayınları.

Eriksen, H. T. (2019). Küçük yerler, büyük meseleler. Sosyal ve kültürel antropoloji. (A. Erkan Koca, çev.). (4.bask1). Ankara: Atıf Yayınlar1.

Erjem, Y. (2018). Toplumsal cinsiyet, hukuk ve suç. D. Şenol \& H.E. Kaya (Ed.), Toplumsal cinsiyet sosyolojisi (ss. 285-310) İstanbul: Lisans Yayıncilik.

Fidan, Z. F. (2016). Yoksulluk kıskacında kadın. İstanbul: Opsiyon Kitap Yayınları. 
Giddens, A. (2008). Küreselleşme ve değişen dünya. H. Özel (Böl. çev.), C. Güzel, (Yay.Haz.) Sosyoloji (ss.101). İstanbul: Kırmızı Yayınlar1.

Giddens, A. (2011). Sosyolojinin savunusu. (İ. Kaya, çev.). İstanbul: Say Yayınları.

Giddens, A. \& Sutton, W. P. (2014). Sosyolojide temel kavramlar. (A. Esgin, çev.). Ankara: Phoenix Yayınları.

Giddens, A. (2014). Mahremiyetin dönüşümü. (İ. Şahin, çev.). (3.baskı). İstanbul: Ayrıntı Yayınları.

Güvenç, B. (1991). Insan ve kültür. (5.bask1). İstanbul: Remzi Kitabevi.

Hanks Wiesner, M. (2020). Tarihte toplumsal cinsiyet. (M. Çiyan Şenerdi, çev.). İstanbul: Türkiye İş Bankası Kültür Yayınları.

Heywood, A. (2013). Küresel siyaset. (N. Uslu ve H. Özdemir, çev.). Ankara: Adres Yayınları.

Hobsbawm, E. (2007). Yeni yüzyılın eşiğinde, söyleşi Antonio Polito. (İ. Yıldız, çev.). İstanbul: Yordam Yayınları.

http://kadincinayetlerinidurduracagiz.net/veriler/2889/kadin-cinayetlerini-durduracagiz-platformu-2019-raporu. (Erişim Tarihi: Temmuz 2020).

İlkkaracan, İ. (2010). "Giriş”, İ. İlkkaracan (Drl.), İş ve aile yaşamını uzlaştırma politikaları (ss. 8-17). İstanbul: İTÜ BMTKAUM ve Kadının İnsan Hakları Yeni Çözümler Derneği Yayınları.

Kaptanoğlu, Y. İ., ve Çavlin, A. (2015). Kadına yönelik şiddet yaygınlığı, İ. Y. Kaptanoğlu, A. Çavlin, A.B. Ergöçmen, vd. (Haz.), Türkiye'de kadına yönelik aile içi şiddet araştırması 2015 (ss. 81-122). Ankara: Hacettepe Üniversitesi Nüfus Etütleri Enstitüsü, Aile ve Sosyal Politikalar Bakanlığı Yayınları.

Korkut, F., ve Owen, W.D. (2008). Kadına yönelik aile içi şiddet. Ankara: Kadının Statüsü Genel Müdürlüğü Yayınları.

Körükmez, L. (2008). Kent yoksulluğu ile mücadelede kadınların geliştirdiği stratejiler ve toplumsal cinsiyet rolleri. N. Oktik (Drl.), Türkiye'de yoksulluk çalışmaları (ss. 207-244). İzmir: Yakın Kitabevi.

Laçiner, Ö. (2011). Bir süreç ve durum olarak yoksullaşmayı sorgulamak. N. Erdoğan (Ed.), Yoksulluk halleri (ss. 313-324). Ankara: İletişim Yayınları.

Parla, J. (2014). Kadın eleştirisi neyi gerçekleştirdi? S. Irzık, J. Parla (Drl.). Kadınlar dile düşünce/Edebiyat ve toplumsal cinsiyet. (ss.15-33). İstanbul: İletişim Yayınları.

Parla, J., ve Irzık, S. (2014). “Önsöz”, S. Irzık, J. Parla (Drl.), Kadınlar dile düşünce/Edebiyat ve toplumsal cinsiyet (ss.7-13). İstanbul: İletişim Yayınları.

Ritzer, G. (2011). Küresel dünya. (M. Pekdemir, çev.), İstanbul: Ayrıntı Yayınları.

Şeker, A. (2020). Edebiyat ve toplumsal cinsiyet. Ankara: Gece Kitaplığı.

Uluocak, Ş. Gökulu, G. Bilir, O. Karacık, E. N., ve Özbay, D. (2014). Toplumsal cinsiyet eşitsizliği ve kadına yönelik şiddet. Edirne: Paradigma Yayınları.

UNDP (Birleşmiş Milletler Kalkınma Programı). (2014). İnsani Gelişme Raporu. https://www.tr.undp.org/content/turkey/tr/home/library/human_development/hdr-2014.html. (Erişim Tarihi: Eylül 2019).

Üner, S. (2008). Toplumsal cinsiyet eşitsizliği. Ankara: Kadının Statüsü Genel Müdürlüğü Yayınları.

Üstün, İ., ve Bora, A. (2005). Sicak aile ortamı/Demokratikleşme sürecinde kadın ve erkekler. İstanbul: TESEV Yayınları.

Zencirkıran, M. (2013). Küreselleşme, küresel sosyal sorunlar ve çözüm arayışları. M. Zencirkıran (Ed.). Türkiye'nin toplumsal yapısı (ss. 412-447). Bursa: Dora Yayınları.

Zeybekoğlu, Ö. (2013). Toplumsal cinsiyet bağlamında erkeklik olgusu. Ankara: Eğiten Kitap Yayınları.

Wallerstein, I. (2012). Tarihsel kapitalizm ve kapitalist uygarlı. (N. Alpay, çev.). İstanbul: Metis Yayınevi. 